Supporting Information

for

\title{
Covalently Bound Gold Nanoparticle-Assisted Epitaxial Growth of Silicon Nanowires
}

\author{
Han Ju Lee,,$\|,{ }^{\dagger}$ Chul Soon Park,,${ }^{\| \dagger}$ Yi-Seul Park,,$\|, \pi$ Rami Aboumourad, ${ }^{\dagger}$ \\ Maria D. Marquez, ${ }^{\dagger}$ Jin Seok Lee,,${ }^{* \neq}$ and T. Randall Lee ${ }^{*}$, \\ ${ }^{\dagger}$ Department of Chemistry and the Texas Center for Superconductivity, University of Houston, \\ 4800 Calhoun Road, Houston, Texas 77204-5003, United States \\ "Materials and Life Science Research Division, Korea Institute of Science and Technology, \\ Seoul 02792, Korea \\ ${ }^{\ddagger}$ Department of Chemistry, Research Institute for Convergence of Basic Sciences, and Research \\ Institute for Natural Sciences, Hanyang University, Seoul 04763, Korea
}

"These authors contributed equally.

*Corresponding Authors: trlee@uh.edu; jseoklee@hanyang.ac.kr 


\section{SYNTHESIS AND CHARACTERIZATION OF THE ADSORBATES}

The monodentate alkenethiol, 17-octadecenethiol (OET), was obtained following synthetic procedures found in the literature. ${ }^{\mathrm{S} 1}$ (5-(Undec-10-en-1-yloxy)-1,3-phenylene)dimethanethiol (UEPDT) was prepared according to Scheme S1. The adsorbate (4-(undec-10-en-1yloxy)phenyl)methanethiol (UEPMT) was prepared according to Scheme S2.

Synthetic Procedures. The procedures used to prepare UEPDT and UEPMT are provided below, as outlined in Scheme S1 and S2, respectively. The experimental details are provided in the following paragraphs.

Scheme S1. Synthetic route used to obtain UEPDT

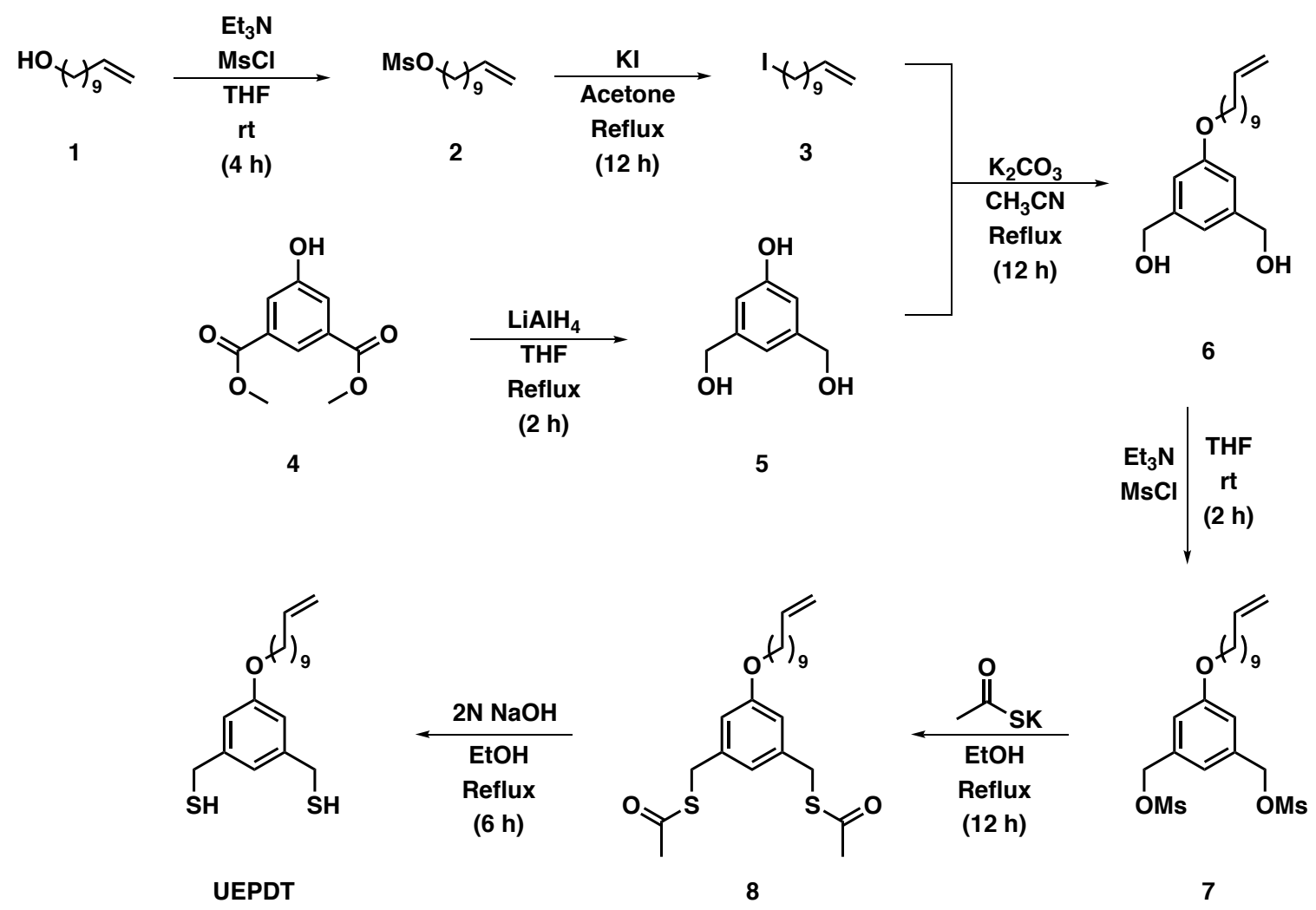

Undec-10-en-1-yl methanesulfonate (2). Undec-10-en-1-ol (10 mL, $50 \mathrm{mmol})$ was introduced onto a $500 \mathrm{~mL}$ round-bottomed flask. Then, an aliquot of triethylamine $(3.9 \mathrm{~mL}, 65 \mathrm{mmol})$ was added slowly into the solution. The reaction mixture was stirred at $\mathrm{rt}$ for $30 \mathrm{~min}$. The reaction flask was placed in an ice bath, and methanesulfonyl chloride $(4.7 \mathrm{~mL}, 65 \mathrm{mmol})$ was transferred slowly to the solution while stirring. The ice bath was then removed and the reaction was stirred 
for $4 \mathrm{~h}$ at rt. After completion of the reaction, excess methanesulfonyl chloride was destroyed with $100 \mathrm{~mL}$ of water. The mixture was extracted with ether $(3 \times 100 \mathrm{~mL})$. The combined organic layers were washed with $2.0 \mathrm{M} \mathrm{HCl}(100 \mathrm{~mL})$ and water $(2 \times 100 \mathrm{~mL})$. The organic layer was dried over $\mathrm{MgSO}_{4}$, filtered, and concentrated in vacuo to produce undec-10-en-1-yl methanesulfonate $(9.8 \mathrm{~g}, 40 \mathrm{mmol})$ which was used in the next step without further purification (80\% yield). ${ }^{1} \mathrm{H}$ NMR $\left(400 \mathrm{MHz}, \mathrm{CDCl}_{3}\right): \delta 5.80(\mathrm{~m}, 1 \mathrm{H}), 4.93(\mathrm{~m}, 2 \mathrm{H}), 4.21(J=6.9 \mathrm{~Hz}, 2 \mathrm{H})$, $2.99(\mathrm{~s}, 3 \mathrm{H}), 2.03(\mathrm{~m}, 2 \mathrm{H}), 1.73(\mathrm{~m}, 2 \mathrm{H}), 1.22-1.50(\mathrm{~m}, 14 \mathrm{H})$.

11-Iodoundec-1-ene (3). Compound $2(9.0 \mathrm{~g}, 36 \mathrm{mmol})$ was suspended in $150 \mathrm{~mL}$ of acetone in a $250 \mathrm{~mL}$ round-bottom flask which contain $\mathrm{KI}(6.6 \mathrm{~g}, 40 \mathrm{mmol})$, and the mixture was refluxed for 12h. After cooling to $\mathrm{rt}$, the resulting organic phase was condensed by a rotary evaporator to produce $8.9 \mathrm{~g}(32 \mathrm{mmol})$ of a pale yellow solid ( $89 \%$ yield). ${ }^{1} \mathrm{H} \mathrm{NMR}\left(400 \mathrm{MHz}, \mathrm{CDCl}_{3}\right): \delta 5.81$ (m, 1H), $4.93(\mathrm{~m}, 2 \mathrm{H}), 3.17(\mathrm{~J}=6.9 \mathrm{~Hz}, 2 \mathrm{H}), 2.02(\mathrm{~m}, 2 \mathrm{H}), 1.78(\mathrm{~m}, 2 \mathrm{H}), 1.20-1.42(\mathrm{~m}, 14 \mathrm{H})$.

3,5-Bis(hydroxymethyl)phenol (5). To a THF (200 mL) suspension of $\mathrm{LiAlH}_{4}(4.00 \mathrm{~g}, 106 \mathrm{mmol})$ was added a THF solution $(50 \mathrm{~mL})$ of dimethyl 5-hydroxyisophthalate $(6.0 \mathrm{~g}, 28 \mathrm{mmol})$ dropwise at $0{ }^{\circ} \mathrm{C}$. The ice bath was then removed, and the reaction mixture was refluxed for $6 \mathrm{~h}$. After completion of the reaction, an aqueous $\mathrm{H}_{2} \mathrm{SO}_{4}$ solution (10\%) was carefully added dropwise at $0{ }^{\circ} \mathrm{C}$ to the mixture until no more hydrogen evolved. The reaction mixture was filtered, and the filtrate was condensed via a rotary evaporator. The crude product was purified via column chromatography $\left(\mathrm{CH}_{2} \mathrm{Cl}_{2}: \mathrm{MeOH}=8: 2\right)$ to produce 3,5-bis(hydroxymethyl)phenol (4.8 g, $\left.30 \mathrm{mmol}\right)$ as a white solid (73\% yield). ${ }^{1} \mathrm{H}$ NMR (400 MHz, $\left.\mathrm{CD}_{3} \mathrm{OD}\right): \delta 6.79(\mathrm{~s}, 1 \mathrm{H}), 6.71(\mathrm{~s}, 2 \mathrm{H}), 4.50$ (s, $4 \mathrm{H})$.

(5-(Undec-10-en-1-yloxy)-1,3-phenylene) dimethanol (6). A mixture of $\mathrm{K}_{2} \mathrm{CO}_{3}(8.1 \mathrm{~g}, 60 \mathrm{mmol})$, 3,5-bis(hydroxymethyl)phenol (4.8 g, $30 \mathrm{mmol})$, and 11-iodoundec-1-ene (3) $(8.9 \mathrm{~g}, 32 \mathrm{mmol})$ in acetonitrile $(100 \mathrm{~mL})$ was refluxed for $12 \mathrm{~h}$. After cooling to rt, the residual $\mathrm{K}_{2} \mathrm{CO}_{3}$ was removed by filtration. The resulting organic phase was condensed by rotary evaporation followed by addition of dichloromethane $(100 \mathrm{~mL})$, and then acidification with $2.0 \mathrm{M} \mathrm{HCl}$ to $\mathrm{pH} \sim 3$. The organic layer was washed with water $(3 \times 50 \mathrm{~mL})$, dried over $\mathrm{MgSO}_{4}$, and concentrated in vacuo to produce $7.6 \mathrm{~g}$ ( $25 \mathrm{mmol})$ of a pale-yellow solid $\left(83 \%\right.$ yield). ${ }^{1} \mathrm{H} \mathrm{NMR}\left(400 \mathrm{MHz}, \mathrm{CDCl}_{3}\right)$ : $\delta 6.90(\mathrm{~s}, 1 \mathrm{H}), 6.82(\mathrm{~s}, 2 \mathrm{H}), 5.81(\mathrm{~m}, 1 \mathrm{H}), 4.93(\mathrm{~m}, 2 \mathrm{H}), 4.64(\mathrm{~s}, 4 \mathrm{H}), 3.95(\mathrm{t}, J=6.4 \mathrm{~Hz}, 2 \mathrm{H}), 2.02$ (m, 2H), $1.78(\mathrm{~m}, 2 \mathrm{H}), 1.20-1.46(\mathrm{~m}, 14 \mathrm{H})$. 
(5-(Undec-10-en-1-yloxy)-1,3-phenylene)bis(methylene) dimethanesulfonate (7). Methyl 16-(3,5bis(hydroxymethyl)phenoxy)hexadecanoate $(7.6 \mathrm{~g}, 18 \mathrm{mmol})$ was introduced into a $500 \mathrm{~mL}$ round-bottomed flask containing $250 \mathrm{~mL}$ of THF and then an aliquot of triethylamine $(7.3 \mathrm{~mL}$, $50 \mathrm{mmol}$ ) was added slowly into the solution. The reaction mixture was stirred at $\mathrm{rt}$ for $30 \mathrm{~min}$. The reaction flask was placed in an ice bath and methanesulfonyl chloride $(6.2 \mathrm{~mL}, 50 \mathrm{mmol})$ was transferred slowly to the solution while stirring. The ice bath was then removed and the reaction was stirred for $4 \mathrm{~h}$ at rt. After completion of the reaction, excess methanesulfonyl chloride was destroyed with $100 \mathrm{~mL}$ of water. The mixture was extracted with ether $(3 \times 100 \mathrm{~mL})$. The combined organic layers were washed with $2.0 \mathrm{M} \mathrm{HCl}(100 \mathrm{~mL})$ and water $(2 \times 100 \mathrm{~mL})$. The organic layer was dried over $\mathrm{MgSO}_{4}$, filtered, and concentrated in vacuo to produce methyl 16(3,5-bis((methylsulfonyloxy)methyl)-phenoxy)hexadecanoate (3.3 g, $10 \mathrm{mmol})$, which was used in the next step without further purification (77\% yield). ${ }^{1} \mathrm{H}$ NMR $\left(400 \mathrm{MHz}, \mathrm{CDCl}_{3}\right): \delta 7.00$ (s, 1H), $6.94(\mathrm{~s}, 2 \mathrm{H}), 5.79$ (m, 1H), $4.93(\mathrm{~m}, 2 \mathrm{H}), 3.95$ (t, $J=6.8 \mathrm{~Hz}, 2 \mathrm{H}), 2.97$ (m, 6H), 2.04 (m, 2H), $1.77(\mathrm{~m}, 2 \mathrm{H}), 1.24-1.47(\mathrm{~m}, 14 \mathrm{H})$.

S,S'-((5-(undec-10-en-1-yloxy)-1,3-phenylene)bis(methylene)) diethanethioate (8). Potassium thioacetate $(4.2 \mathrm{~g}, 25 \mathrm{mmol})$ was dissolved in $100 \mathrm{~mL}$ of ethanol under nitrogen. Methyl 16-(3,5bis((methylsulfonyloxy)methyl)phenoxy)hexadecanoate $(3.3 \mathrm{~g}, 10 \mathrm{mmol})$ was added dropwise to the stirred solution over $5 \mathrm{~min}$. The reaction mixture was then refluxed for $4 \mathrm{~h}$. After cooling, the precipitate was filtered off, rinsed with ethanol, and the resulting organic phase was evaporated to dryness. The residue was taken up by a blend of dichloromethane $(100 \mathrm{~mL})$ and water $(100 \mathrm{~mL})$. The mixture was extracted with dichloromethane $(3 \times 100 \mathrm{~mL})$. The combined organic layers were washed with brine $(3 \times 100 \mathrm{~mL})$, dried over anhydrous $\mathrm{MgSO}_{4}$, filtered and concentrated via rotary evaporation. The crude product was purified by column chromatography (hexanes:ethyl acetate $=3: 1)$ to produce $2.1 \mathrm{~g}(5.0 \mathrm{mmol})$ of methyl 16-(3,5-bis(acetylthiomethyl)phenoxy)hexadecanoate as a white solid (50\% yield). ${ }^{1} \mathrm{H}$ NMR (400 MHz, $\left.\mathrm{CDCl}_{3}\right): \delta 6.75(\mathrm{~s}, 1 \mathrm{H}), 6.69(\mathrm{~s}, 2 \mathrm{H})$, $5.79(\mathrm{~m}, 1 \mathrm{H}), 4.93(\mathrm{~m}, 2 \mathrm{H}), 4.03(\mathrm{~s}, 4 \mathrm{H}), 3.90(\mathrm{t}, J=6.4 \mathrm{~Hz}, 2 \mathrm{H}), 2.34(\mathrm{~s}, 6 \mathrm{H}), 2.02(\mathrm{~m}, 2 \mathrm{H}), 1.73$ (m, 2H), 1.25-1.43 (m, 14H).

(5-(Undec-10-en-1-yloxy)-1,3-phenylene)dimethanethiol (UEPDT). An ethanolic solution $(20 \mathrm{~mL})$ of methyl 16-(3,5-bis(acetylthiomethyl)phenoxy)hexadecanoate $(2.1 \mathrm{~g}, 5.0 \mathrm{mmol})$ was purged of oxygen by bubbling nitrogen gas through the solution for $30 \mathrm{~min}$. To the solution was added $2.0 \mathrm{M} \mathrm{NaOH}(40 \mathrm{~mL})$, and the mixture was refluxed for $6 \mathrm{~h}$. After cooling in an ice bath, 
the reaction mixture was acidified to $\mathrm{pH} \sim 3$ with $1.0 \mathrm{M} \mathrm{HCl}$. The precipitate product was then separated, washed with ether $(3 \times 30 \mathrm{~mL})$, and then dried under vacuum. The crude product was purified by column chromatography $\left(\mathrm{CHCl}_{3}: \mathrm{MeOH}=9.9: 0.1\right)$ to give $0.4 \mathrm{~g}(1.1 \mathrm{mmol})$ of 16(3,5-bis(mercaptomethyl)phenoxy)hexadecanoic acid as a white solid (22\% yield). ${ }^{1} \mathrm{H}$ NMR $\left(400 \mathrm{MHz}, \mathrm{CDCl}_{3}\right): \delta 6.84(\mathrm{~s}, 1 \mathrm{H}), 6.73(\mathrm{~s}, 2 \mathrm{H}), 5.79(\mathrm{~m}, 1 \mathrm{H}), 4.93(\mathrm{~m}, 2 \mathrm{H}), 3.93(\mathrm{t}, J=6.8 \mathrm{~Hz}$, $2 \mathrm{H}), 3.67(\mathrm{~d}, J=7.7 \mathrm{~Hz}, 2 \mathrm{H}), 2.02(\mathrm{~m}, 2 \mathrm{H}), 1.74(\mathrm{~m}, 2 \mathrm{H}), 1.24-1.47(\mathrm{~m}, 14 \mathrm{H}) .{ }^{13} \mathrm{C}$ NMR $\left(100 \mathrm{MHz}, \mathrm{CDCl}_{3}\right): \delta 159.7,142.9,139.3,119.9,114.2,112.9,68.1,33.9,29.6,29.5,29.5,29.3$, $29.2,29.0,26.1$.

Scheme S2. Synthetic route used to obtain UEPMT

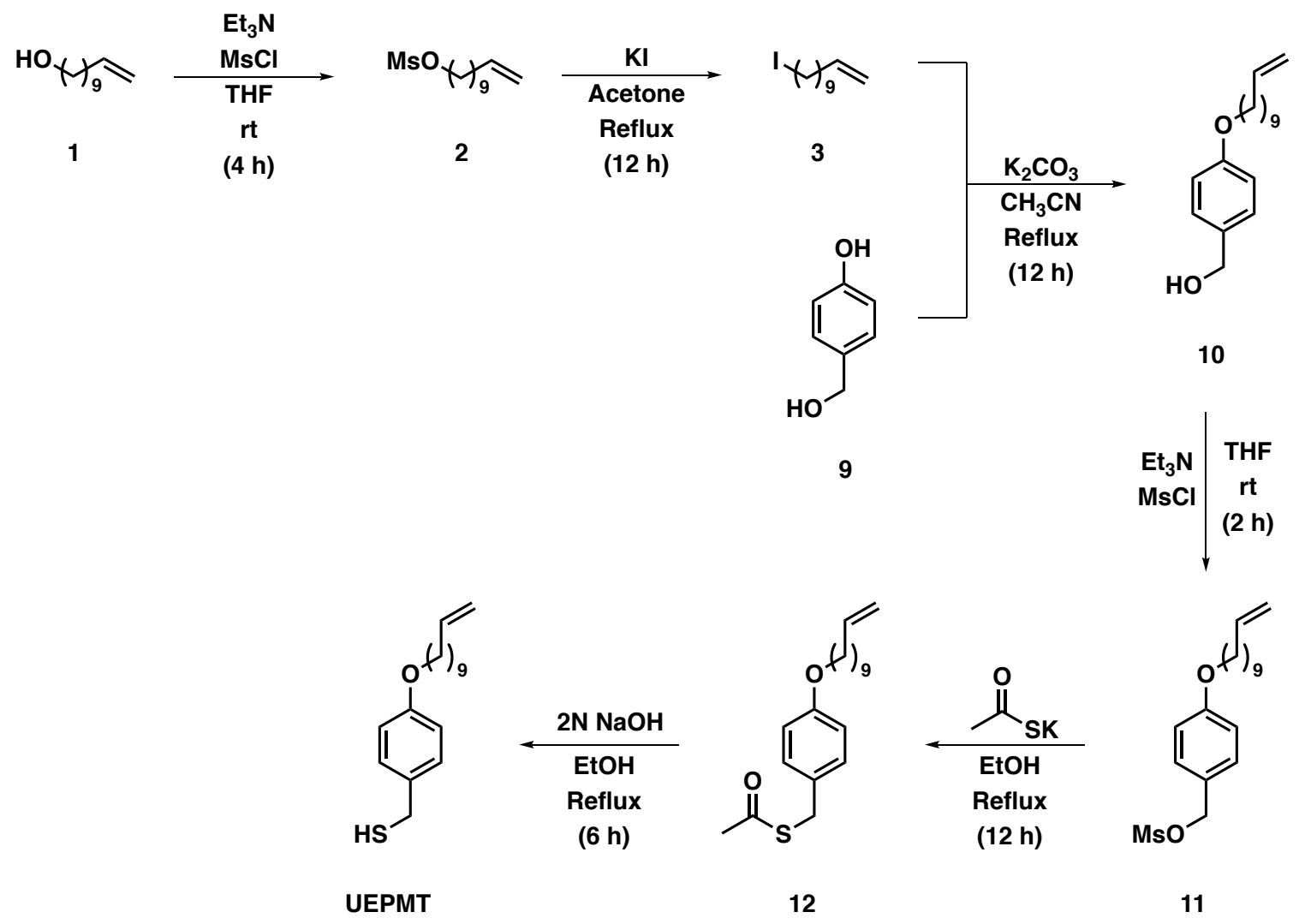

(4-(Undec-10-en-1-yloxy)phenyl)methanol (10). Following an analogous procedure described for 6, a mixture of $\mathrm{K}_{2} \mathrm{CO}_{3}(6.9 \mathrm{~g}, 50 \mathrm{mmol})$, 4-(hydroxymethyl)phenol (3.1 g, $\left.25 \mathrm{mmol}\right)$, and methyl 11-iodoundec-1-ene $(8.0 \mathrm{~g}, 28 \mathrm{mmol})$ in acetonitrile $(100 \mathrm{~mL})$ was refluxed to give $5.1 \mathrm{~g}(18 \mathrm{mmol})$ of a pale yellow solid (75\% yield). ${ }^{1} \mathrm{H}$ NMR $\left(400 \mathrm{MHz}, \mathrm{CDCl}_{3}\right): \delta 7.27(\mathrm{~d}, J=8.7 \mathrm{~Hz}, 2 \mathrm{H}), 6.87$ $(\mathrm{d}, J=8.7 \mathrm{~Hz}, 2 \mathrm{H}), 5.79(\mathrm{~m}, 1 \mathrm{H}), 4.93(\mathrm{~m}, 2 \mathrm{H}), 4.60(\mathrm{~s}, 2 \mathrm{H}), 3.93(\mathrm{t}, J=6.4 \mathrm{~Hz}, 2 \mathrm{H}), 2.02(\mathrm{~m}$, $2 \mathrm{H}), 1.76(\mathrm{~m}, 2 \mathrm{H}), 1.20-1.56(\mathrm{~m}, 14 \mathrm{H})$. 
4-(Undec-10-en-1-yloxy)benzyl methanesulfonate (11). Following an analogous procedure described for 7, a mixture of $\mathbf{1 0}(5.0 \mathrm{~g}, 18 \mathrm{mmol})$ and triethylamine $(3.6 \mathrm{~mL}, 25 \mathrm{mmol})$ in $250 \mathrm{~mL}$ of THF was treated with methanesulfonyl chloride $(2.0 \mathrm{~mL}, 15 \mathrm{mmol})$ to give $4.5 \mathrm{~g} \mathrm{(14} \mathrm{mmol})$ of methyl 16-(4-((methylsulfonyloxy)methyl)phenoxy)hexadecanoate $(80 \%$ yield $) . \quad{ }^{1} \mathrm{H} \quad \mathrm{NMR}$ $\left(400 \mathrm{MHz}, \mathrm{CDCl}_{3}\right): \delta 7.27(\mathrm{~d}, J=8.7 \mathrm{~Hz}, 2 \mathrm{H}), 6.87(\mathrm{~d}, J=8.7 \mathrm{~Hz}, 2 \mathrm{H}), 5.80(\mathrm{~m}, 1 \mathrm{H}), 4.96(\mathrm{~m}$, 2H), $4.06(\mathrm{~s}, 2 \mathrm{H}), 3.93(\mathrm{t}, J=6.4 \mathrm{~Hz}, 2 \mathrm{H}), 2.02(\mathrm{~m}, 2 \mathrm{H}), 1.76(\mathrm{~m}, 2 \mathrm{H}), 1.20-1.56(\mathrm{~m}, 14 \mathrm{H})$.

S-(4-(Undec-10-en-1-yloxy)benzyl) ethanethioate (12). Following an analogous procedure described for 8, a mixture of $\mathbf{1 1}(4.5 \mathrm{~g}, 14 \mathrm{mmol})$ and potassium thioacetate $(3.1 \mathrm{~g}, 13 \mathrm{mmol})$ in ethanol $(200 \mathrm{~mL})$ was stirred under reflux to give the crude product. The crude product was purified by column chromatography (hexanes:ethyl acetate $=3: 1)$ to produce $2.3 \mathrm{~g}(7.0 \mathrm{mmol})$ of methyl 16-(4-(acetylthiomethyl)phenoxy)hexadecanoate as a white solid (50\% yield). ${ }^{1} \mathrm{H}$ NMR $\left(400 \mathrm{MHz}, \mathrm{CDCl}_{3}\right): \delta 7.18(\mathrm{~d}, J=8.7 \mathrm{~Hz}, 2 \mathrm{H}), 6.80(\mathrm{~d}, J=8.7 \mathrm{~Hz}, 2 \mathrm{H}), 5.80(\mathrm{~m}, 1 \mathrm{H}), 4.96(\mathrm{~m}$, 2H), 4.06 (s, 2H), 3.91 (t, $J=6.4 \mathrm{~Hz}, 2 \mathrm{H}), 2.33(\mathrm{~s}, 3 \mathrm{H}), 2.02(\mathrm{~m}, 2 \mathrm{H}), 1.75(\mathrm{~m}, 2 \mathrm{H}), 1.21-1.46(\mathrm{~m}$, $14 \mathrm{H})$.

(4-(Undec-10-en-1-yloxy)phenyl)methanethiol (UEPMT). Following an analogous procedure described for UEPDT, a solution of methyl $S$-(4-(Undec-10-en-1-yloxy)benzyl) ethanethioate $(2.3 \mathrm{~g}, 7.0 \mathrm{mmol})$ in a 50:50 blend of ethanol and THF $(40 \mathrm{~mL})$ was treated with $2.0 \mathrm{M} \mathrm{NaOH}(20$ $\mathrm{mL}$ ) to obtain the product. The crude product was purified by column chromatography $\left(\mathrm{CHCl}_{3}: \mathrm{MeOH}=9.9: 0.1\right)$ to give $0.49 \mathrm{~g}(1.7 \mathrm{mmol})$ of 16-(4-(mercaptomethyl)phenoxy)hexadecanoic acid as a white solid (25\% yield). ${ }^{1} \mathrm{H}$ NMR (400 MHz, $\left.\mathrm{CDCl}_{3}\right): \delta 7.22(\mathrm{~d}, J=8.7 \mathrm{~Hz}$, 2H), $6.82(\mathrm{~d}, J=8.7 \mathrm{~Hz}, 2 \mathrm{H}), 5.81(\mathrm{~m}, 1 \mathrm{H}), 4.93(\mathrm{~m}, 2 \mathrm{H}), 3.91$ (t, $J=6.8 \mathrm{~Hz}, 2 \mathrm{H}), 3.68$ (d, $J=7.3$ $\mathrm{Hz}, 2 \mathrm{H}), 2.02(\mathrm{~m}, 2 \mathrm{H}), 1.75(\mathrm{~m}, 2 \mathrm{H}), 1.21-1.46(\mathrm{~m}, 14 \mathrm{H}) .{ }^{13} \mathrm{C} \mathrm{NMR}\left(100 \mathrm{MHz}, \mathrm{CDCl}_{3}\right): \delta 158.1$, 139.3, 129.2, 114.7, 68.1, 33.9, 29.6, 29.5, 29.5, 29.4, 29.2, 29.0, 26.2. 


\section{SPECTRAL DATA}

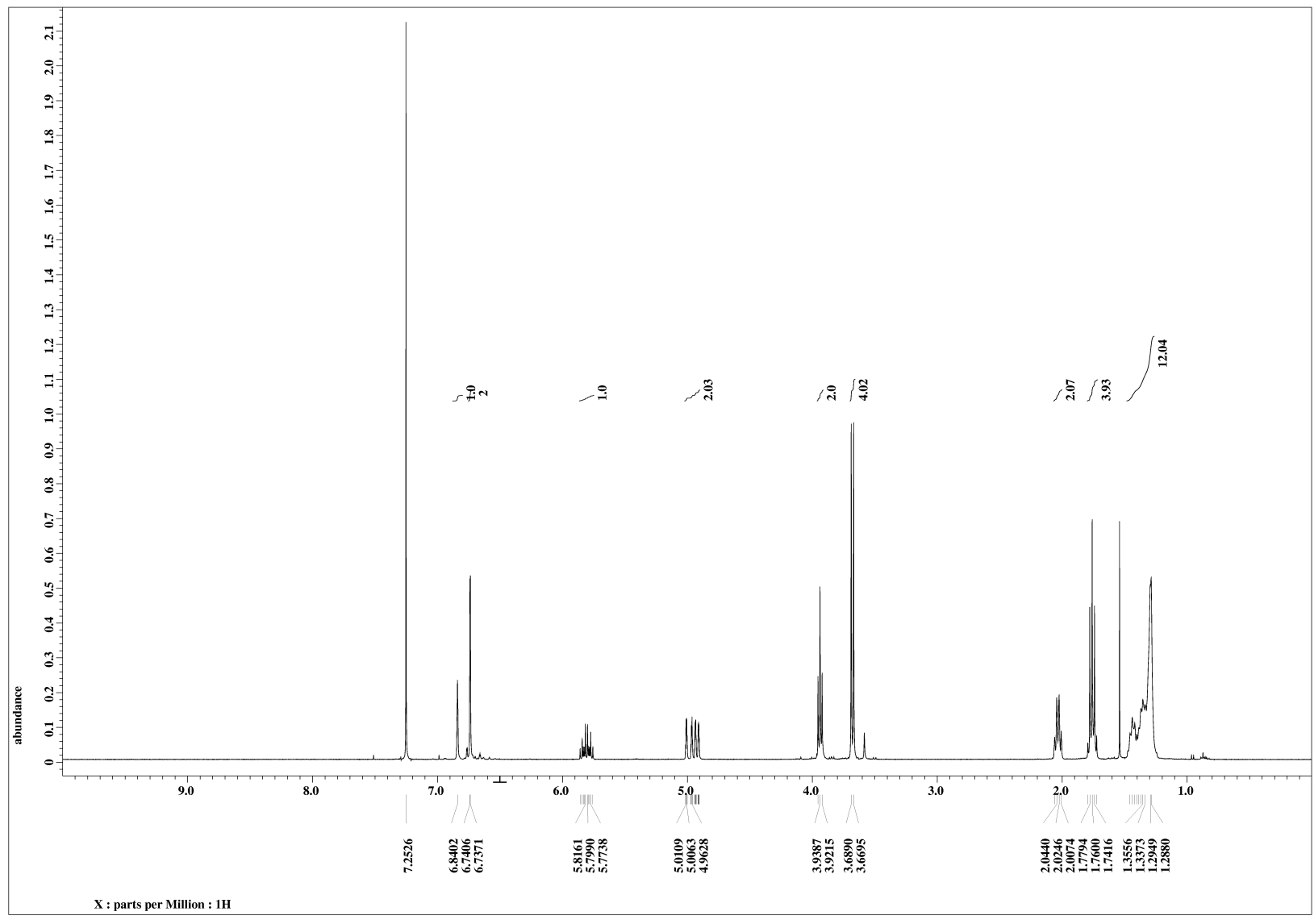

Figure S1. ${ }^{1} \mathrm{H}$ NMR spectrum of (5-(undec-10-en-1-yloxy)-1,3-phenylene)dimethanethiol (UEPDT). 


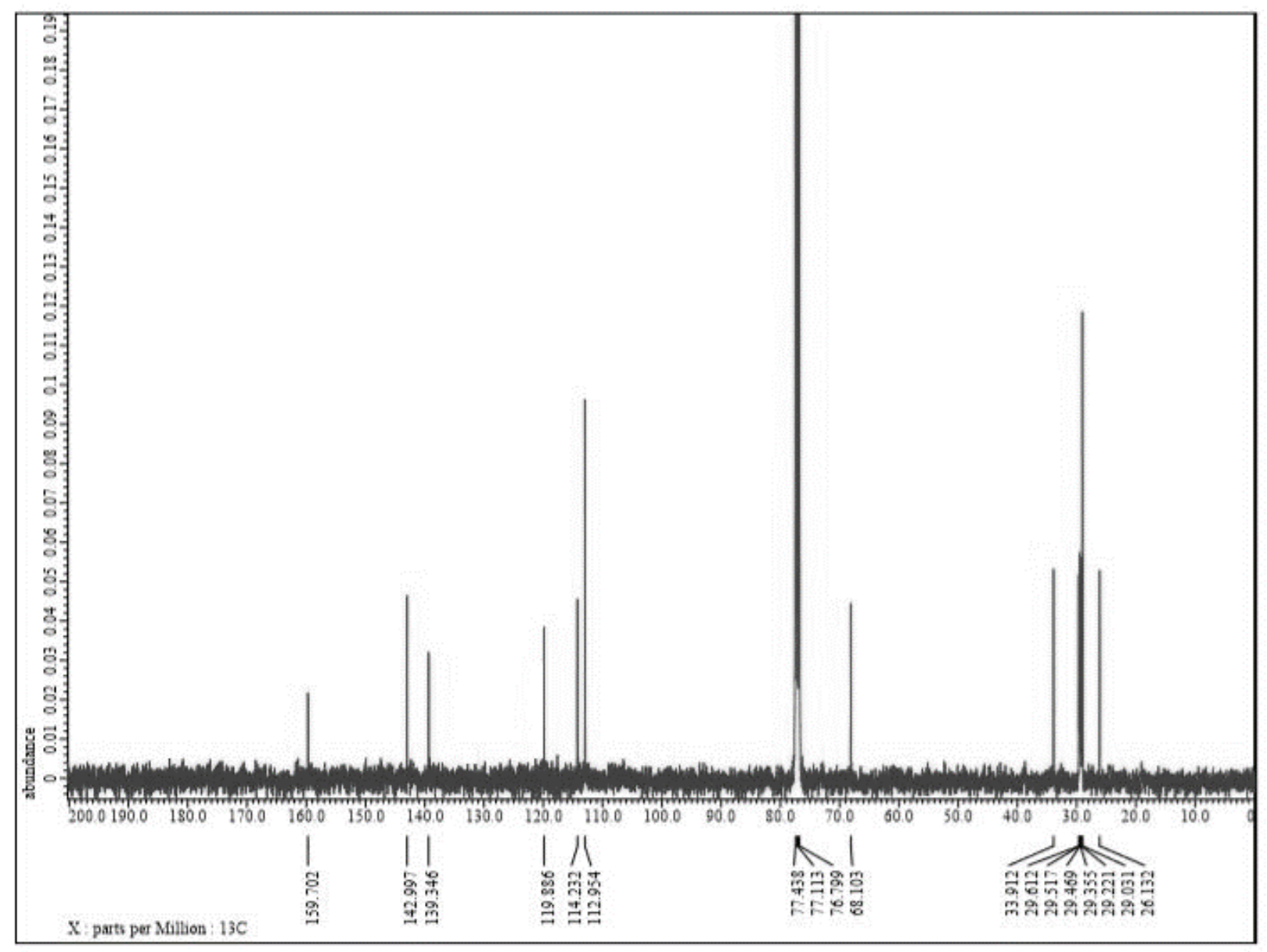

Figure S2. ${ }^{13} \mathrm{C}$ NMR spectrum of (5-(undec-10-en-1-yloxy)-1,3-phenylene)dimethanethiol (UEPDT). 


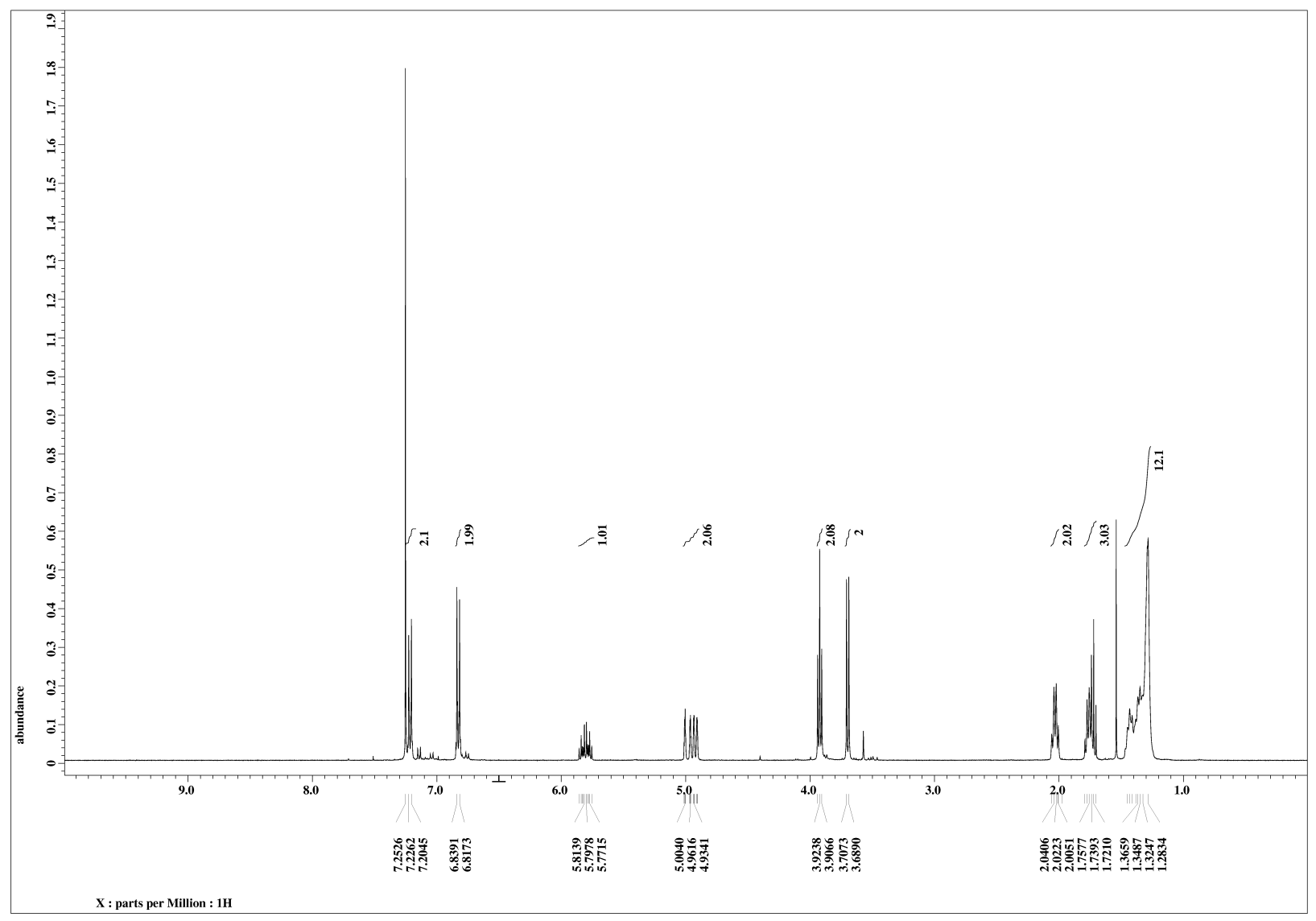

Figure S3. ${ }^{1} \mathrm{H}$ NMR spectrum of (4-(undec-10-en-1-yloxy)phenyl)methanethiol (UEPMT). 


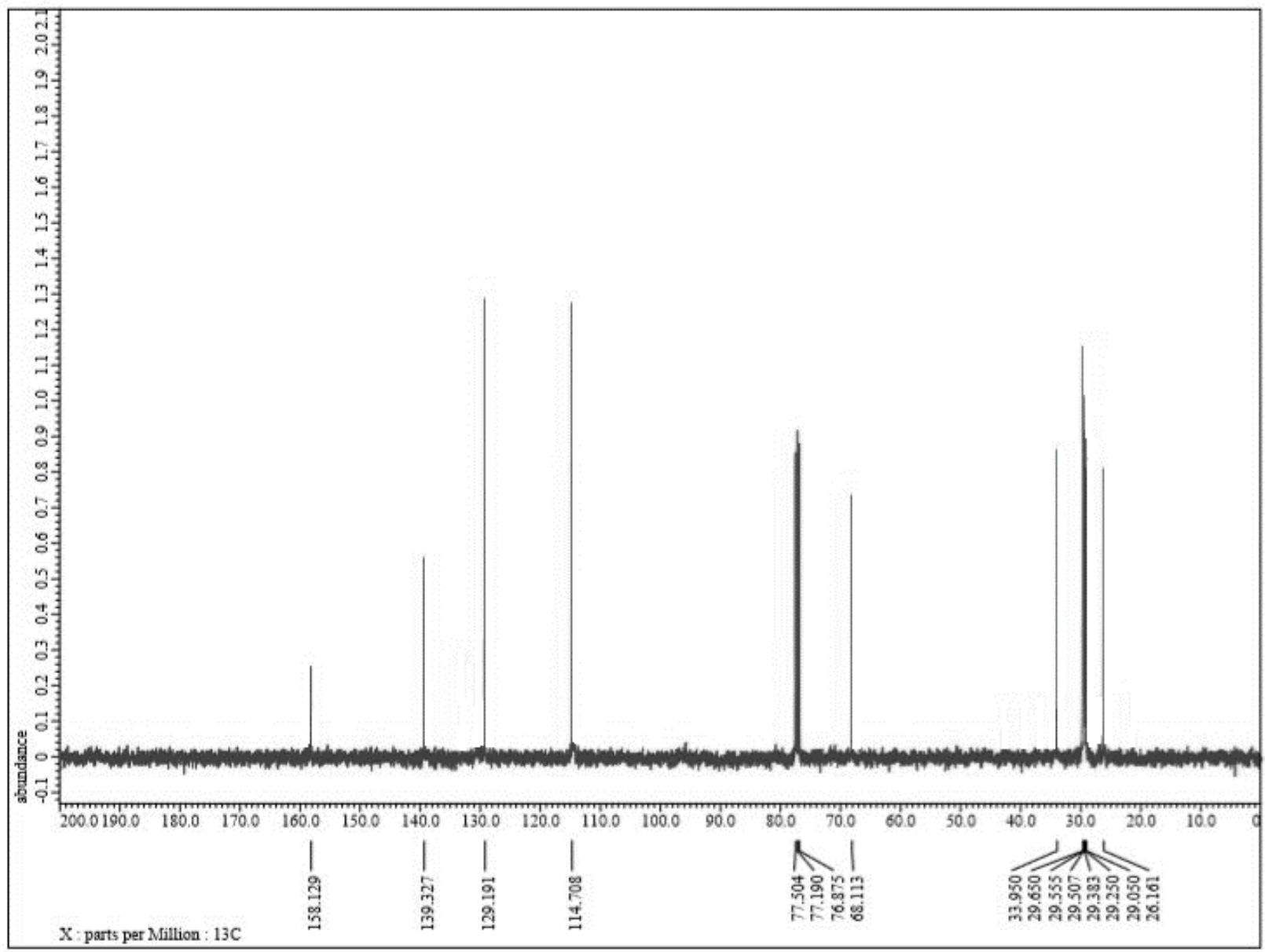

Figure S4. ${ }^{13} \mathrm{C}$ NMR spectrum of (4-(undec-10-en-1-yloxy)phenyl)methanethiol (UEPMT).

\section{REFERENCES}

(S1) Katherine, C. H.; Justin, M, David, B.; Pawilai, C.; Lee, T. R.; Steven, B. Sum Frequency Generation Imaging Microscopy of Patterned SAMs with Terminal $-\mathrm{CH}_{3},-\mathrm{OCH}_{3},-\mathrm{CF}_{2} \mathrm{CF}_{3}$, $-\mathrm{C}=\mathrm{C}$, - Phenyl, and -Cyclopropyl Groups. J. Phys. Chem. C. 2008, 112, 14529-14537. 